Review

\title{
Fatty Acid Hydratases: Versatile Catalysts to Access Hydroxy Fatty Acids in Efficient Syntheses of Industrial Interest
}

\author{
Jana Löwe and Harald Gröger *(D) \\ Industrial Organic Chemistry and Biotechnology, Faculty of Chemistry, Bielefeld University, \\ Universitätsstraße 25, 33615 Bielefeld, Germany; jana.loewe@uni-bielefeld.de \\ * Correspondence: harald.groeger@uni-bielefeld.de; Tel.: +49-521-106-2057
}

Received: 21 December 2019; Accepted: 17 February 2020; Published: 3 March 2020

check for updates

\begin{abstract}
The utilization of hydroxy fatty acids has gained more and more attention due to its applicability in many industrial building blocks that require it, for example, polymers or fragrances. Furthermore, hydroxy fatty acids are accessible from biorenewables, thus contributing to a more sustainable raw material basis for industrial chemicals. Therefore, a range of investigations were done on fatty acid hydratases (FAHs), since these enzymes catalyze the addition of water to an unsaturated fatty acid, thus providing an elegant route towards hydroxy-substituted fatty acids. Besides the discovery and characterization of fatty acid hydratases (FAHs), the design and optimization of syntheses with these enzymes, the implementation in elaborate cascades, and the improvement of these biocatalysts, by way of mutation in terms of the substrate scope, has been investigated. This mini-review focuses on the research done on process development using fatty acid hydratases as a catalyst. It is notable that biotransformations, running at impressive substrate loadings of up to $280 \mathrm{~g} \mathrm{~L}^{-1}$, have been realized. A further topic of this mini-review is the implementation of fatty acid hydratases in cascade reactions. In such cascades, fatty acid hydratases were, in particular, combined with alcohol dehydrogenases (ADH), Baeyer-Villiger monooxygenases (BVMO), transaminases (TA) and hydrolases, thus enabling access to a broad variety of molecules that are of industrial interest.
\end{abstract}

Keywords: biocatalysis; cascades; enzymes; fatty acids; hydratases; hydroxy fatty acids

\section{Introduction}

Hydroxy fatty acids are of the highest interest for industrial applications, since they serve as starting materials for polymers [1] or cyclic lactones [2], which are used in fragrances and antibiotics [3], as well as in plasticizers [4], surfactants [5], lubricants [6] and detergent formulations [7]. Besides being available in nature and accessible through plant oil hydrolysis (e.g., in the case of ricinoleic acid from castor oil [8]), chemical approaches towards hydroxy-functionalized fatty acids include oxygenation, epoxidation [9-11] and ozonolysis [12] as key reaction steps. Enzymatically, hydroxy fatty acids can be synthesized by means of oxidation reactions in the presence of 12-hydroxylases [13], cytochrome P450 monooxygenases, lipoxygenases, and peroxygenases [12]. An enzyme-class, which catalyzes the addition of water to non-activated $\mathrm{C}=\mathrm{C}$ double bonds are hydratases. Representative examples for such enzymes are the linalool dehydratase-isomerase, which converts myrcene towards linool [14], or carotenoid 1,2-hydratase [15], which catalyzes the conversion of acyclic carotenes. However, one of the most common enzymes for the conversion of unsaturated, non-activated $\mathrm{C}=\mathrm{C}$-double bonds are fatty acid hydratases (FAHs) [16,17]. Hydratases can only be found in microorganisms [18]. After being reported for the first time by Wallen et al. in 1962 [19], they gained high interest since [20,21]. Until now, no detailed statements can be made about the physiological role of fatty acid hydratases. Some 
possible functions are the detoxification of fatty acids [22] or changes in host-microbe interactions due to their capacity to enhance cell hydrophobicity [23]. FAHs are FAD-dependent enzymes [24], in which the FAD seems to stabilize the active conformation. The FAD, which is none-covalently bound to the conserved N-terminal nucleotide binding motif (GXGXXGX21E/D) [25], is, however, not involved in the reaction mechanism for the hydration of the unsaturated fatty acid [22,25]. Furthermore, there are a range of structural prerequisites for the substrates in order to be tolerated by this enzyme class. Accordingly, fatty acid hydratases require a carboxylic group in the substrate, a distance of nine carbons between the double bond and the acid group, a minimum chain length of C-14 and a cis-conformation of the double bond [26]. For these substrates, the hydration then proceeds by the simple addition of water, which makes such a transformation a highly attractive reaction, which is also the case for industrial purposes.

\section{Application of Fatty Acid Hydratase in Synthesis and Process Development}

The utilization of enzymes in the chemical industry has become indispensable, and today numerous large-scale applications, based on the use of enzymes, are already known [27-33]. Industrial processes that use enzymes as a catalyst often have excellent productivities. Well-known examples are the production of acrylamide [34] in the presence of a nitrile hydratase or the use of lipases for the hydrolysis of milk fat, oils and fat [27]. In addition, the industry also makes use of the naturally high stereoselectivity of enzymes, and representative examples in this field are the enzymatic production of L-amino acids by means of an aminoacylase [35] or the use of a penicillin acylase for the production of antibiotics [36].

A further enzyme class with broad potential applicability for industrial purpose are fatty acid hydratases, which are capable of hydrating unsaturated fatty acids, thus forming hydroxy-substituted fatty acids [37]. This type of reaction only requires water as a reagent, which also makes this transformation attractive from the point of view of sustainability. Since fatty acids are key components of fats and oils as renewable raw materials, this type of biotransformation is also of interest within the current research efforts to develop processes for industrial chemicals based on biorenewable feedstocks instead of petrochemical sources. In Figure 1, a representative example for such a transformation with a fatty acid hydratase is shown, exemplified by the synthesis of 10-hydroxyoctadecanoic acid starting from oleic acid.

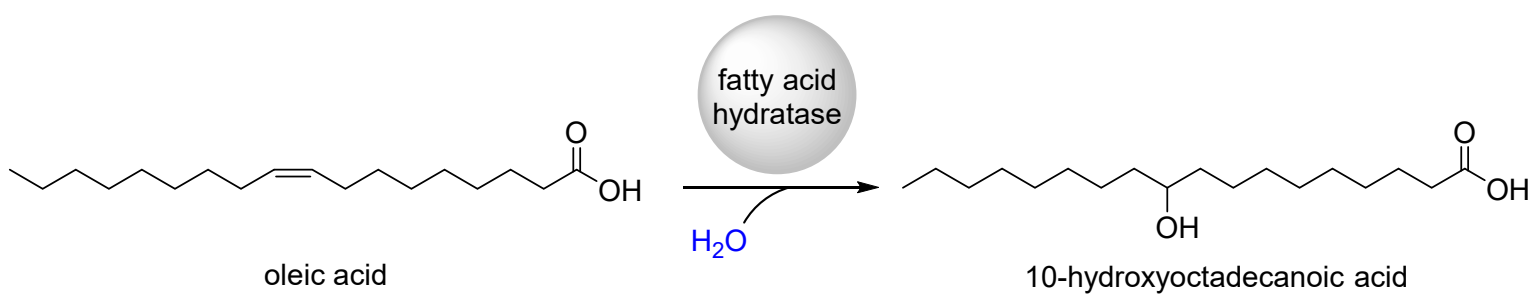

Figure 1. Reaction scheme for the synthesis of 10-hydroxyoctadecanoic acid starting from oleic acid as a selected example for the synthesis of hydrated fatty acids [37].

The characterization of fatty acid hydratases has been intensively studied, as well as the process development of hydroxy fatty acid production by means of this approach. One of the first applications of hydroxy fatty acid hydratases in the process development for the synthesis of hydroxy fatty acids is the use of the strain Candida tropicalis DSM 3152 and a mutant M 25 in the transformation of oleic acid into 3-hydroxy- $\Delta^{9}$-cis-1,18-octadecenedioic acid, which gave the desired product with $19.4 \mathrm{~g} \mathrm{~L}^{-1}$ after $223 \mathrm{~h}$ in the fermentation process [38]. In addition, a range of other comprehensive studies, including other microbes, which possess the ability to convert unsaturated fatty acids into hydroxy fatty acids, were published, such as resting Saccharomyces cerevisiae cells [39], ruminal bacteria [40] or bacteria isolated from compost or soil [41,42], to name just a few, which converts oleic acid into 10-hydroxyoctadecanoic acid. In 2009, one of the most frequently used fatty acid hydratases was 
described for the first time. In detail, the isolation and biochemical characterization of the oleate hydratase from Elizabethkingia meningoseptica (formerly known as Pseudomonas sp. strain 3266 and widely found in nature, e.g., in soil and water) [43], was reported by Hagen et al. [44]. In 2011, Oh et al. described a fatty acid hydratase of Stenotrophomonas nitritireducens, the genus Stenotrophomonas lives in close association with plants [45], and by means of the corresponding whole cells containing this enzyme, with $31.5 \mathrm{~g}$ of 10-hydroxystearic in $4 \mathrm{~h}$, were formed when starting from $30 \mathrm{~g}$ of oleic acid [46]. Since 2012, the interest in the development of fatty acid hydratases and its usage in elevated gram-scale applications further increased.

In 2012, Oh et al. described a putative fatty acid hydratase, which was isolated from Stenotrophomonas maltophilia and was defined as an oleate hydratase. In the presence of this enzyme, 10-hydroxystearic acid was obtained with $49 \mathrm{~g} \mathrm{~L}^{-1}$ in $4 \mathrm{~h}$, corresponding to a conversion of $98 \%$ [37]. The same group also reported a recombinant enzyme from Lysinibacillus fusiformis (organism isolated from soil) [47], which was isolated and defined as an oleate hydratase. Under optimized reaction conditions, $40 \mathrm{~g} \mathrm{~L}^{-1}(133 \mathrm{mM})$ of the desired product 10-hydroxystearic acid was isolated, which corresponds to a yield of 94\% [48]. Park et al. used the oleate hydratase from Stenotrophomonas maltophilia and recombinantly expressed the ohyA gene in E. coli. This biocatalyst was able to produce 10-hydroxystearic acid with a final concentration of $46 \mathrm{~g} \mathrm{~L}^{-1}$ in the culture medium [49]. Subsequently, Oh et al. described a process with an oleate hydratase from Lysinibacillus fusiformis, which converted ricinoleic acid to 10,12-dihydroxystearic acid, which was obtained with $13.5 \mathrm{~g} \mathrm{~L}^{-1}$ [50]. Lactobacillus species are mostly found in dairy products, such as fermented milks and cheeses [51]. Additionally, Ogawa et al. classified genes that can be found in the gut bacterium Lactobacillus plantarum, encoding for enzymes, which are involved in the metabolism of polyunsaturated fatty acids [52]. Moreover, the LAH (Lactobacillus acidophilus hydratase) was described as a hydratase [53], whereas, in the same year, the crystal structure of this enzyme in the apo form was determined, showing a structural similarity to the 10,12-CLA-producing fatty acid double-bond isomerase from Propionibacterium acnes (PAI) and an amine oxidoreductase from Calloselasma rhodostoma. This crystallization gave an insight into the protein, which consist of two identical monomers, whereas an additional domain at the C-terminus acts as a lid, which covers the entrance of the substrate-binding channel. This lid probably opens through the recognition of the carboxylate residue on the surface of the enzyme. The opening of one channel led to the opening of the other protomer [54]. In 2014, Oh et al. described a fatty acid hydratase from Stenotrophomonas nitritireducens, which converted $5.3 \mathrm{~g} \mathrm{~L}^{-1}$ linoleic acid and $0.93 \mathrm{~g} \mathrm{~L}^{-1}$ oleic acid [55]. The same group also utilized a linoleate 13-hydratase from Lactobacillus acidophilus to convert linoleic acid to hydroxy fatty acid via the use of recombinant whole cells, which produced $79 \mathrm{~g} \mathrm{~L}^{-1}$ within 3 h [56]. In 2015, Ogawa et al. described a further gut bacterium (Lactobacillus acidophilus NTV001), which expresses a gene called FA-HY1 that is suitable to convert C18, as well as C20 and C22 unsaturated fatty acids [57]. Additionally, Oh et al. identified a double-bond hydratase that produces 13(S)-hydroxy-9(Z)-octadecenoic acid with high stereoselectivity [12]. Another milestone was the clarification of the crystal structure of Elizabethkingia meningoseptica, which also shows FAD as a bound cofactor. These findings gave a deep insight into the process of enzymatic water addition to $\mathrm{C}=\mathrm{C}$ double bonds. The postulated mechanism starts with the protonation of the double bond by the means of a tyrosine. This positive charge is on the one hand stabilized by FAD and on the other hand by the means of an asparagine and a phenylalanine, which are localized at the C-terminus of a $\alpha$-helix. A water-molecule, which is activated by a glutamate, then is able to attack on the partially charged double bond [25].

The production of a hydroxylated fatty acid at very high substrate loading could be achieved with the fatty acid hydratase of Lactobacillus plantarum, which was overexpressed in E. coli and used for the conversion of $280 \mathrm{~g} \mathrm{~L}^{-1}$ linoleic acid into (S)-10-hydoxy-cis-12-octadecenoic acid (HYA), leading to an enantiomeric excess (ee) of $>99 \%$ [58]. In addition, Oh et al. described an oleate hydratase from Stenotrophomonas nitritireducens, which converts plant oils to 10-hydroxy fatty acids. Hauer et al. summarized, in the Hydratase Engineering Database (HyED) 2046, putative oleate hydratases from 
eleven homologous families [59]. Moreover, Oh et al. used a 10-hydratase from Stenotrophomonas maltophilia DSM 29579 and 13-hydratase from Lactobacillus acidophilus ATCC 4796 for the conversion of 31.7 and $15.6 \mathrm{~g} \mathrm{~L}^{-1}$ of unsaturated fatty acids in OA-rich oil [60]. All hydroxy fatty acids, which have been synthesized from fatty acids at substrate loadings that are on a multi gram per liter scale, are listed in Table 1, together with further information on experimental data. Additionally, all characterized oleate hydratases are categorized in two groups, namely OhyA1 or OhyA2. This categorization is based on the fourth conserved amino acid of the flavin adenine dinucleotide (FAD)-binding motif [61]. Moreover, it is possible to use a plant oil as a cheap and renewable [62] starting material in combination with a hydroxy fatty acid hydratase and a lipase.

Furthermore, several examples of the synthesis of hydroxy fatty acids, starting from the cleavage of the oils (Figure 2), have been demonstrated, and in the following, some selected examples are given. Kim et al. used a lipase from Candida rugosa to hydrolyze olive and soybean oil, and the resulting fatty acids were then further converted by means of the Flavobacterium sp. strain DS5, which was used to oxygenate fatty acids, thus leading to 10-ketostearic acid as major product and a minor amount of 10-hydroxystearic acid when starting from olive oil [63]. Candida rugosa can also be used for the hydrolysis of safflower oil [43], as well as perilla seed oil [55,64] and tree oils [65]. The lipase from Thermomyces lanuginosus is able to hydrolyze olive and soybean oil [66].<smiles>[R]C(=O)OCC(COC([R])=O)OC(=O)[R](O)C([R])=O</smiles>

Figure 2. Enzymatic hydrolysis of oils, thus releasing fatty acids and glycerol. 
Table 1. Summary of fatty acid hydratases and resulting products synthesized on multi gram-scale. Exp. in E. coli: expressed in E. coli; - : no information was given.

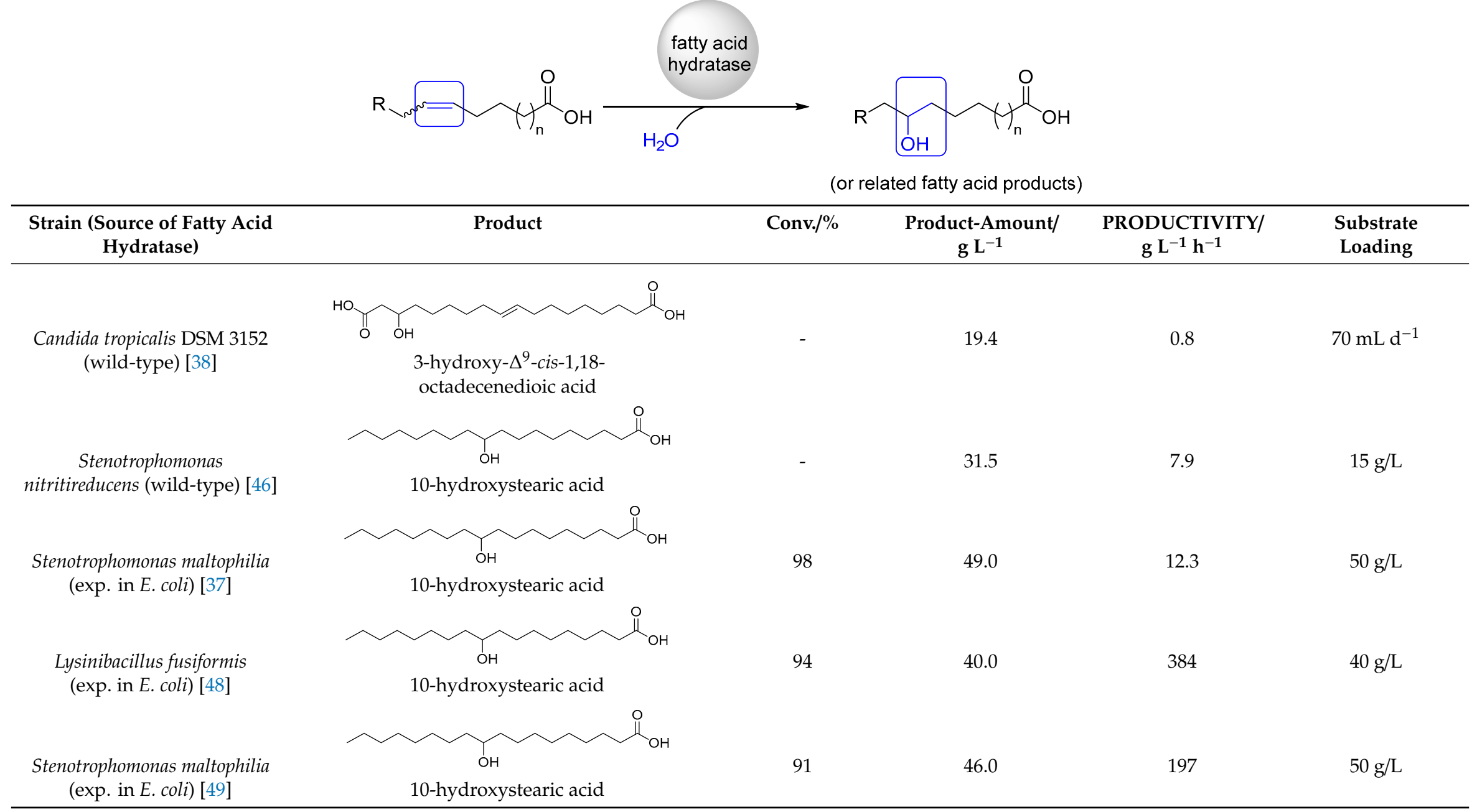


Table 1. Cont

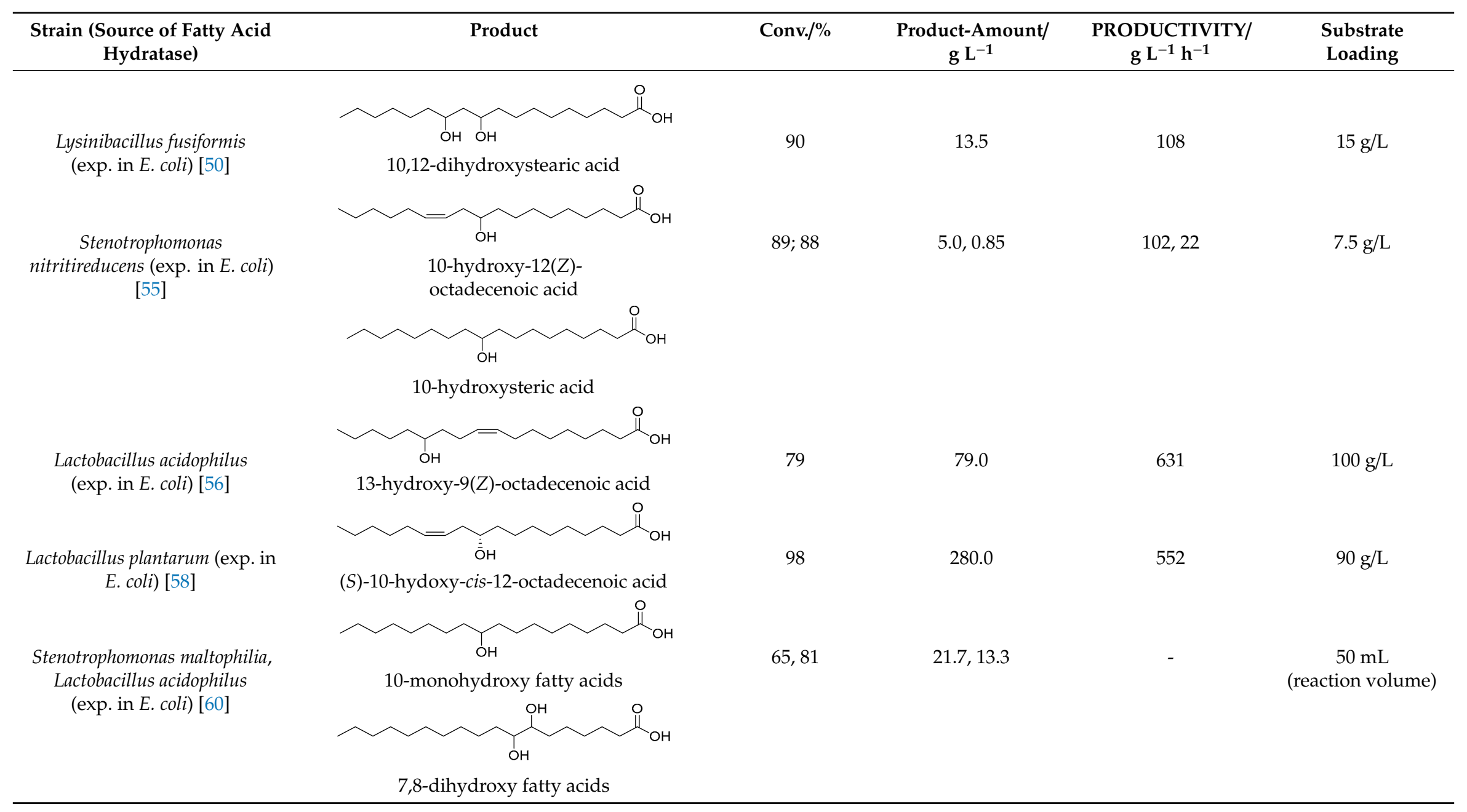




\section{Cascade Processes Involving Fatty Acid Hydratase}

From the year 2013 on, a range of enzymatic cascades combining fatty acid hydratases with other enzymes have been reported in the literature. In such cascades, fatty acid hydratases, in combination with other enzymes, were used to build-up a broad range of industrially relevant products. Such cascades combining various enzymatic steps are of interest also from an industrial perspectives as work-steps of intermediates can be avoided, thus enabling a better process economy with decreased solvent consumption and solvent waste formation. A key prerequisite (and at the same time a challenge) for realizing such cascades is to achieve compatibility between the different enzymatic reaction steps.

Examples of the usage of fatty acid hydratases in biocatalytic cascade processes for the synthesis of long-chain $\alpha, \omega$-dicarboxylic acids and $\omega$-hydroxycarboxylic acids are summarized in Figure 3 and are described in the following. Park et al. developed a cascade starting with a hydratase catalyzing the hydration of the fatty acid double bond. Afterwards, the alcohol is oxidized by means of an alcohol dehydrogenase (ADH) and a Baeyer-Villiger monooxygenase (BVMO). In the final step, the ester is then hydrolysed towards $\alpha, \omega$-dicarboxylic acids and $\omega$-hydroxycarboxylic acids (Figure 4 ). All these enzymes were combined in one whole cell, and the process was conducted without addition of an external cofactor. Such products are of particular interest for applications in the field of polymers as these bifunctional molecules can serve as monomers for the synthesis of corresponding polyesters [67].

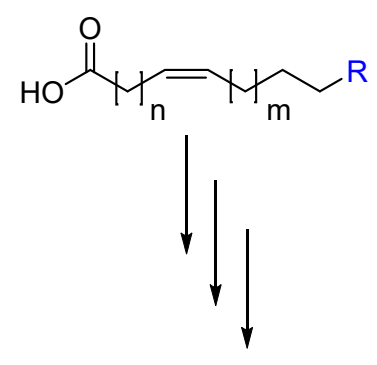<smiles>O=C(O)CCCCCCO</smiles>

polymer area, lubricants, plasticizers, perfumes<smiles>NCCCCCCCCCCC(=O)O</smiles><smiles>O=C(O)CCCCCCCC(=O)O</smiles>

polymer area, lubricants, plasticizers, perfumes<smiles>O=C(O)CCCCCCCC(=O)O</smiles>

flavors, resins, waxes, nylons, plastics, lubricants, polymers<smiles>CC(N)CCCCCCCC(=O)O</smiles><smiles>O=C(O)CC=CCCCO</smiles>

flavors, resins, waxes, nylons, plastics, lubricants, polymers<smiles>CCCCCCC(=O)CCC(=O)O</smiles>

flavors, resins, waxes, nylons, plastics, lubricants, polymers<smiles>CCCCCCC1CCC(=O)O1</smiles>

flavorin

Figure 3. Collection of different molecules that were synthesized in a cascade that involve fatty acid hydratases. Listed are $\omega$-hydroxycarboxylic acids [66] $\alpha, \omega$-dicarboxylic acids [68], aminocarboxylic acids [68,69], oxostearic acid [70] and lactones [2]. 


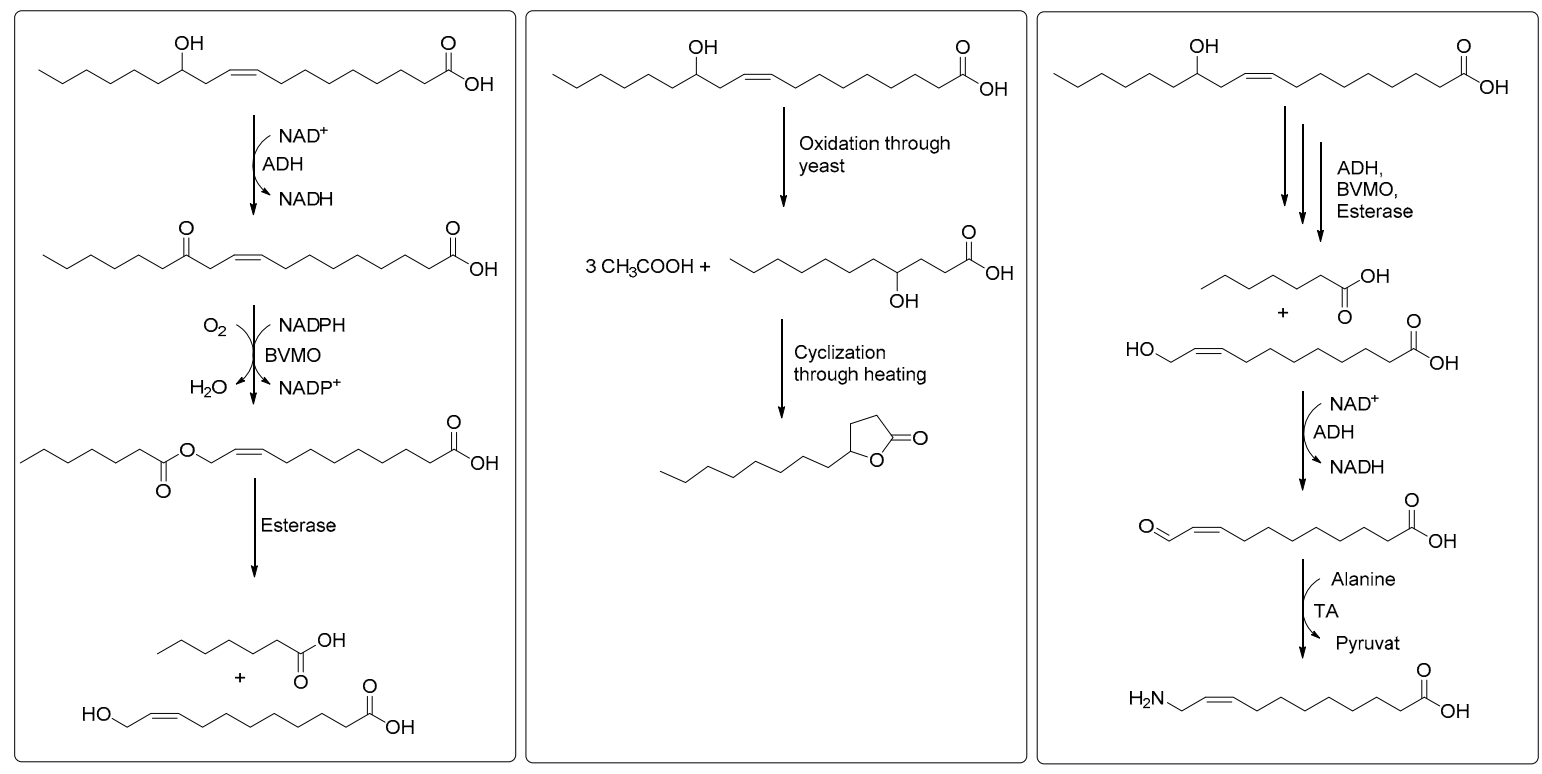

Figure 4. Chosen examples for the enzymatic cascade reactions involving fatty acid hydratases. Shown are the synthesis of $\omega$-hydroxycarboxylic acid [67], $\omega$-aminocarboxylic acids [68,69] and $\gamma$-lactone [2]. NAD/NADH (Nicotinamide adenine dinucleotide), ADH (Alcohol dehydrogenase), BVMO (Bayer-Villiger monooxygenase), TA (Transaminase).

Besides being interesting building blocks as starting materials in the polymer field, these products can be also utilized for the preparation of lubricants, plasticizers or perfumes [70]. This cascade process was then further expanded by coupling the cascade with an alcohol dehydrogenase, which oxidized the $\omega$-hydroxycarboxylic acid towards the corresponding diacid or the aldehyde [67]. The latter one is subsequently transformed via a transaminase towards the primary amine (Figure 4) [67]. It is noteworthy that, by means of this concept, fatty acids can be converted into $\omega$-substituted amino acids, which are of interest as monomers for polyamides.

Furthermore, this cascade was combined with a double bond hydratase to obtain unsaturated $\alpha, \omega$-dicarboxylic acids and $\omega$-hydroxycarboxylic acids [71,72]. In addition, a related cascade system using a whole cell catalyst, which overexpresses a fatty acid double bond hydratase (OhyA) of Stenotrophomonas maltophilia, the ADH of Micrococcus luteus, and the engineered Baeyer-Villiger monooxygenase (E6BVMO) of Pseudomonas putida KT2440, was developed. Furthermore, the long chain fatty acid transporter FadL was overexpressed, which transports the fatty acids into the whole cell. This overexpression further contributes to the improvement of the whole-cell biotransformation. It should be added that this cascade starts and ends with a hydrolysis. In the initial step, a plant oil is hydrolyzed, and the final step consists of the hydrolysis of the ester by the means of a lipase from Thermomyces lanuginosus. The $\omega$-hydroxycarboxylic acid is then further derivatized by means of chemical [64] or enzymatic oxidation, and the resulting product can then further be used as a monomer for the production of polyesters and polyamides [73]. This synthetic method was further extended towards a process based on the use of a whole cell catalyst, which converts long chain fatty acids like ricinoleic acid, in combination with an added aldehyde dehydrogenase, in order to obtain the corresponding $\omega$-hydroxycarboxylic acid (Figure 4) [74].

In further studies by $\mathrm{Xu}$ et al., the synthesis of 10-oxostearic acid was reported, utilizing a novel oleate hydratase from Paracoccus aminophilus with a high specific activity of $5.21 \mathrm{U} \mathrm{mg}^{-1}$. In the hydration step, $90 \mathrm{~g} \mathrm{~L}^{-1}$ of hydrated oleic acid was obtained. The formed 10-hydroxystearic was converted afterwards by an alcohol dehydrogenase from Micrococcus luteus, which was used in combination with a lactate dehydrogenase for co-factor recycling. After $10 \mathrm{~h}$ reaction time at a scale of $1 \mathrm{~L}$, a conversion of $95 \%$ was reached [69]. This concept also shows the high suitability of 
combining a lyase (exemplified by a hydratase) and redox enzymes (exemplified by alcohol and lactate dehydrogenases).

Another building block that is of interest for a different industrial product segment was synthesized by Oh et al. in 2014, which also utilize fatty acid hydratases. In detail, they produced $\gamma$-dodecalactone from safflower oil, which is widely used in perfume industry or enhancing aroma or taste [55]. The cascade starts with the hydrolysis of safflower oil by means of lipase from Candida rugosa producing free fatty oleic and linoleic acid. Afterwards, the hydration was catalyzed by the FAH from Stenotrophomonas nitritireducens, followed by lactonization in the presence of these Candida boidinii whole cells [57].

Furthermore, Park et al. very recently published a cascade for the production of aliphatic amines from renewable fatty acids, which are interesting for applications in the polymer area such as for the synthesis of carbamates and polyurethanes [67]. This concept is based on the combined use of three types of enzymes, namely a fatty acid hydratase, an alcohol dehydrogenase and a transaminases [68].

\section{Conclusions}

The importance of fatty acid hydratases in biotechnology has been demonstrated by the many achievements of different groups, including the development of suitable biocatalysts, microorganisms or isolated enzymes overexpressed in E. coli. The biocatalysts were further used for the process development of fatty acid hydration in huge scale applications, producing industrially relevant hydroxy-substituted fatty acids from renewable raw materials, such as, e.g., vegetable oils as raw material. Nevertheless, high cell or enzyme amounts were used, as well as no elaborate isolation methods being presented, which is a bottleneck for further utilization. Moreover, the combination of fatty acid hydration with other enzymes in complex cascade processes was intensively studied for the further production of industrially valuable molecules. However, up to now, only little is known about the catalytic mechanism, which is due to the fact that only a limited number of crystal structures are available $[25,54,75,76]$. The advanced knowledge could contribute to the future improvement of productivity and the design of novel biotransformation pathways. Other confines are the substrate scope, which is limited by the seven carbon atoms between carboxylic residue and double bond, as well as the length of the fatty acids and the carboxylic acid itself. These problems have already been addressed in some publications, like the hydration of unactivated olefins by using short chain acids as decoy molecules [77], the rational of engineering a fatty acid hydratase to enhance the substrate scope [78] and the hydration of oleic acid derivatives without a free carboxylate moiety [79]. Thus, the current status represents a highly promising basis for further studies in this field with the perspective of a range of industrial applications for a sustainable manufacture of industrial chemicals for various commercial segments, based on the utilization of biorenewable raw materials.

Author Contributions: Conceptualization, J.L. and H.G.; writing—original draft preparation, J.L.; writing—review and editing, J.L. and H.G.; supervision, H.G. All authors have read and agreed to the published version of the manuscript.

Funding: This work was funded by the U. Windmöller Innovation GmbH \& Co. KG.

Acknowledgments: J.L. and H.G. thank the U. Windmöller Innovation GmbH \& Co. KG for financial support.

Conflicts of Interest: The authors declare no conflict of interest.

\section{References}

1. Liu, C.; Liu, F.; Cai, J.; Xie, U.W.; Long, T.E.; Turner, S.R.; Lyons, A.; Gross, R.A. Polymers from Fatty Acids: Poly (Co-Hydroxyl Tetradecanoic Acid) Synthesis and Physico-Mechanical Studies. ACS Symp. Ser. 2012, 1105, 131-150. [CrossRef]

2. Świzdor, A.; Panek, A.; Milecka-Tronina, N.; Kołek, T. Biotransformations Utilizing $\beta$-Oxidation Cycle Reactions in the Synthesis of Natural Compounds and Medicines. Int. J. Mol. Sci. 2012, 13, 16514-16543. [CrossRef] [PubMed] 
3. Schneider, S.; Wubbolts, M.G.; Sanglard, D.; Witholt, B. Production of Chiral Hydroxy Long Chain Fatty Acids by Whole Cell Biocatalysis of Pentadecanoic Acid with an E. Coli Recombinant Containing Cytochrome P450BM-3 Monooxygenase. Tetrahedron Asymmetry 2002, 9, 2832-2844. [CrossRef]

4. Ashby, R.D.; Solaiman, D.K.Y.; Liu, C.K.; Strahan, G.; Latona, N. Sophorolipid-Derived Unsaturated and Epoxy Fatty Acid Estolides as Plasticizers for Poly (3-Hydroxybutyrate). Am. Oil Chem. Soc. 2016, 93, 347-358. [CrossRef]

5. Hu, J.; Jin, Z.; Chen, T.Y.; Polley, J.D.; Cunningham, M.F.; Gross, R.A. Anionic Polymerizable Surfactants from Biobased $\omega$-Hydroxy Fatty Acids. Macromolecules 2014, 47, 113-120. [CrossRef]

6. Mutlu, H.; Meier, M.A.R. Castor Oil as a Renewable Resource for the Chemical Industry. Eur. J. Lipid Sci. Technol. 2010, 112, 10-30. [CrossRef]

7. Hou, C.T. Biotechnology for Fats and Oils: New Oxygenated Fatty Acids. New Biotechnol. 2009, 26, 2-10. [CrossRef]

8. Patel, V.R.; Dumancas, G.G.; Viswanath, L.C.K.; Maples, R.; Subong, B.J.J. Castor Oil: Properties, Uses, and Optimization of Processing Parameters in Commercial Production. Lipid Insights 2016, LPI-S40233. [CrossRef]

9. Knothe, G.; Weisleder, D.; Bagby, M.O.; Peterson, R.E. Hydroxy Fatty Acids through Hydroxylation of Oleic Acid with Selenium Dioxide/Tert.-Butylhydroperoxide. J. Am. Oil Chem. Soc. 1993, 70, 401-404. [CrossRef]

10. Mountanea, O.G.; Limnios, D.; Kokotou, M.G.; Bourboula, A.; Kokotos, G. Asymmetric Synthesis of Saturated Hydroxy Fatty Acids and Fatty Acid Esters of Hydroxy Fatty Acids. Eur. J. Org. Chem. 2019, 10, $2010-2019$. [CrossRef]

11. Köckritz, A.; Martin, A. Oxidation of Unsaturated Fatty Acid Derivatives and Vegetable Oils. Eur. J. Lipid Sci. Technol. 2008, 110, 812-824. [CrossRef]

12. Kim, K.R.; Oh, H.J.; Park, C.S.; Hong, S.H.; Park, J.Y.; Oh, D.K. Unveiling of Novel Regio-Selective Fatty Acid Double Bond Hydratases from Lactobacillus Acidophilus Involved in the Selective Oxyfunctionalization of Mono- and Di-Hydroxy Fatty Acids. Biotechnol. Bioeng. 2015, 112, 2206-2213. [CrossRef] [PubMed]

13. Van de Loo, F.; Broun, P.; Turner, S.; Somervillet, C. An oleate 12-hydroxylase from Ricinus communis L. is a fatty acyl desaturase homolog. Proc. Natl. Acad. Sci. USA 1995, 92, 6743-6747. [CrossRef] [PubMed]

14. Brodkorb, D.; Gottschall, M.; Marmulla, R.; Lüddeke, F.; Harder, J. Linalool Dehydratase-Isomerase, a Bifunctional Enzyme in the Anaerobic Degradation of Monoterpenes. J. Biol. Chem. 2010, 285, 30436-30442. [CrossRef] [PubMed]

15. Steiger, S.; Mazet, A.; Sandmann, G. Heterologous Expression, Purification, and Enzymatic Characterization of the Acyclic Carotenoid 1, 2-Hydratase from Rubrivivax Gelatinosus. Arch. Biochem. Biophys. 2003, 414, 51-58. [CrossRef]

16. Bornscheuer, U.T. Enzymes in Lipid Modification. Annu. Rev. Food Sci. Technol. 2018, 9, 116-127. [CrossRef]

17. Engleder, M.; Pichler, H. On the Current Role of Hydratases in Biocatalysis. Appl. Microbiol. Biotechnol. 2018, 102, 5841-5858. [CrossRef]

18. Wallen, L.L.; Benedict, R.G.; Jackson, W.R. The Microbiological Production from Oleic of 10-Hydroxystearic Acid from Oleic Acid. Arch. Biochem. Biophys. 1962, 99, 249-253. [CrossRef]

19. Kim, K.-R.; Oh, D.-K. Production of hydroxy fatty acids by microbial fatty acid-hydroxylation enzymes. Biotechnol. Adv. 2013, 31, 1473-1485. [CrossRef]

20. Wallen, L.L.; Davis, E.N.; Wu, Y.V.; Rohwedder, W.K. Stereospecific Hydration of Unsaturated Fatty Acids by Bacteria. Lipids 1971, 6, 745-750. [CrossRef]

21. Niehaus, W.G.; Schroepfer, G.J. The Reversible Hydration of Oleic Acid to 10D-Hydroxystearic Acid. Biochem. Biophys. Res. Commun. 1965, 21, 271-275. [CrossRef]

22. Volkov, A.; Liavonchanka, A.; Kamneva, O.; Fiedler, T.; Goebel, C.; Kreikemeyer, B.; Feussner, I. Myosin Cross-Reactive Antigen of Streptococcus Pyogenes M49 Encodes a Fatty Acid Double Bond Hydratase That Plays a Role in Oleic Acid Detoxification and Bacterial Virulence. J. Biol. Chem. 2010, 285, 10353-10361. [CrossRef] [PubMed]

23. Chen, Y.Y.; Liang, N.Y.; Curtis, J.M.; Gänzle, M.G. Characterization of Linoleate 10-Hydratase of Lactobacillus plantarum and Novel Antifungal Metabolites. Front. Microbiol. 2016, 7, 1561. [CrossRef] [PubMed] 
24. Rosberg-Cody, E.; Liavonchanka, A.; Göbel, C.; Ross, R.P.; O'Sullivan, O.; Fitzgerald, G.F.; Feussner, I.; Stanton, C. Myosin-Cross-Reactive Antigen (MCRA) Protein from Bifidobacterium Breve Is a FAD-Dependent Fatty Acid Hydratase Which Has a Function in Stress Protection. BMC Biochem. 2011, 12, 1-12. [CrossRef] [PubMed]

25. Engleder, M.; Pavkov-Keller, T.; Emmerstorfer, A.; Hromic, A.; Schrempf, S.; Steinkellner, G.; Wriessnegger, T.; Leitner, E.; Strohmeier, G.A.; Kaluzna, I.; et al. Structure-Based Mechanism of Oleate Hydratase from Elizabethkingia Meningoseptica. ChemBioChem 2015, 16, 1730-1734. [CrossRef] [PubMed]

26. Hiseni, A.; Arends, I.W.C.E.; Otten, L.G. New Cofactor-Independent Hydration Biocatalysts: Structural, Biochemical, and Biocatalytic Characteristics of Carotenoid and Oleate Hydratases. ChemCatChem 2015, 7, 29-37. [CrossRef]

27. Villeneuve, P.; Muderhwa, J.M.; Graille, J.; Haas, M.J. Customizing Lipases for Biocatalysis: A Survey of Chemical, Physical and Molecular Biological Approaches. J. Mol. Catal. B Enzym. 2000, 9, 113-148. [CrossRef]

28. Goldberg, K.; Schroer, K.; Lütz, S.; Liese, A. Biocatalytic Ketone Reduction-A Powerful Tool for the Production of Chiral Alcohols-Part II: Whole-Cell Reductions. Appl. Microbiol. Biotechnol. 2007, 76, 249-255. [CrossRef]

29. Breuer, M.; Ditrich, K.; Habicher, T.; Hauer, B.; Keßeler, M.; Stürmer, R.; Zelinski, T. Industrial Methods for the Production of Optically Active Intermediates. Angew. Chem. Int. Ed. 2004, 43, 788-824. [CrossRef]

30. Strohmeier, G.A.; Pichler, H.; May, O.; Gruber-Khadjawi, M. Application of Designed Enzymes in Organic Synthesis. Chem. Rev. 2011, 111, 4141-4164. [CrossRef]

31. Abdelraheem, E.M.M.; Busch, H.; Hanefeld, U.; Tonin, F. Biocatalysis explained: From pharmaceutical to bulk chemical production. React. Chem. Eng. 2019, 4, 1878-1894. [CrossRef]

32. Jemli, S.; Ayadi-Zouari, D.; Hlima, H.B.; Bejar, S. Biocatalysts: Application and engineering for industrial purposes. Crit. Rev. Biotechnol. 2016, 36, 246-258. [CrossRef] [PubMed]

33. Liese, A.; Seelbach, K.; Wandrey, C. Industrial Biotransformations; Wiley-VCH: Weinheim, Germany, 2006. [CrossRef]

34. Yamada, H.; Nagasawa, T. Production of Useful Amides by Enzymatic Hydration of Nitriles. Agric. Chem. 1990, 613, 142-154. [CrossRef]

35. Miyazawa, T. Enzymatic Resolution of Amino Acids via Ester Hydrolysis. Amino Acids 1999, 16, $191-213$. [CrossRef] [PubMed]

36. Brugging, A.; Roos, E.C.; De Vroom, E. Penicillin Acylase in the Industrial Production of $\beta$-Lactam Antibiotics. Org. Process Res. Dev. 1998, 2, 128-133. [CrossRef]

37. Joo, Y.C.; Seo, E.S.; Kim, Y.S.; Kim, K.R.; Park, J.B.; Oh, D.K. Production of 10-Hydroxystearic Acid from Oleic Acid by Whole Cells of Recombinant Escherichia Coli Containing Oleate Hydratase from Stenotrophomonas Maltophilia. J. Biotechnol. 2012, 158, 17-23. [CrossRef]

38. Fabritius, D.; Schäfer, H.J.; Steinbüchel, A. Identification and Production of 3-Hydroxy- $\Delta 9-C i s-1$, 18-Octadecenedioic Acid by Mutants of Candida Tropicalis. Appl. Microbiol. Biotechnol. 1996, 45, 342-348. [CrossRef]

39. El-Sharkawy, S.H.; Yang, W.; Dostal, L.; Rosazza, J.P.N. Microbial Oxidation of Oleic Acid. Appl. Environ. Microbiol. 1992, 58, 2116-2122. [CrossRef]

40. Hudson, J.A.; MacKenzie, C.A.M.; Joblin, K.N. Conversion of Oleic Acid to 10-Hydroxystearic Acid by Two Species of Ruminal Bacteria. Appl. Microbiol. Biotechnol. 1995, 44, 1-6. [CrossRef]

41. Kaneshiro, T.; Kuo, T.M.; Nakamura, L.K. Conversion of Unsaturated Fatty Acids by Bacteria Isolated from Compost. Curr. Microbiol. 1999, 38, 250-255. [CrossRef]

42. Koritala, S.; Hou, C.T.; Hesseltine, C.W.; Bagby, M.O. Microbial Conversion of Oleic Acid to 10-Hydroxystearic Acid. Appl. Microbiol. Biotechnol. 1989, 32, 299-304. [CrossRef]

43. Shinha, T.; Ahuja, R. Bacteremia due to Elizab. Meningoseptica 2015, 2, 13-15. [CrossRef]

44. Bevers, L.E.; Pinkse, M.W.H.; Verhaert, P.D.E.M.; Hagen, W.R. Oleate Hydratase Catalyzes the Hydration of a Nonactivated Carbon-Carbon Bond. J. Bacteriol. 2009, 191, 5010-5012. [CrossRef]

45. Ryan, R.P.; Monchy, S.; Cardinale, M.; Taghavi, S.; Crossman, L.; Avison, M.B.; Berg, G.; van der Lelie, D.; Dow, J.M. The versatility and adaptation of bacteria from the genus Stenotrophomonas. Nat. Rev. Microbiol. 2019, 7, 514-525. [CrossRef]

46. Kim, B.N.; Yeom, S.J.; Oh, D.K. Conversion of Oleic Acid to 10-Hydroxystearic Acid by Whole Cells of Stenotrophomonas Nitritireducens. Biotechnol. Lett. 2011, 33, 993-997. [CrossRef] 
47. Gallegos-Monterrosa, R.; Maróti, G.; Bálint, B.; Kovács, A.T. Draft Genome Sequence of the Soil Isolate Lysinibacillus fusiformis M5, a Potential Hypoxanthine Producer. Genome Announc. 2016, 4, e01272-16. [CrossRef]

48. Kim, B.N.; Joo, Y.C.; Kim, Y.S.; Kim, K.R.; Oh, D.K. Production of 10-Hydroxystearic Acid from Oleic Acid and Olive Oil Hydrolyzate by an Oleate Hydratase from Lysinibacillus fusiformis. Appl. Microbiol. Biotechnol. 2012, 95, 929-937. [CrossRef]

49. Jeon, E.Y.; Lee, J.H.; Yang, K.M.; Joo, Y.C.; Oh, D.K.; Park, J.B. Bioprocess Engineering to Produce 10Hydroxystearic Acid from Oleic Acid by Recombinant Escherichia Coli Expressing the Oleate Hydratase Gene of Stenotrophomonas Maltophilia. Process Biochem. 2012, 47, 941-947. [CrossRef]

50. Seo, M.H.; Kim, K.R.; Oh, D.K. Production of a Novel Compound, 10, 12-Dihydroxystearic Acid from Ricinoleic Acid by an Oleate Hydratase from Lysinibacillus fusiformis. Appl. Microbiol. Biotechnol. 2013, 97, 8987-8995. [CrossRef]

51. De Angelis, M.; Gobbetti, M. Lactobacillus spp.: General Characteristics. Ref. Modul. Food Sci. 2016. [CrossRef]

52. Kishino, S.; Takeuchi, M.; Park, S.B.; Hirata, A.; Kitamura, N.; Kunisawa, J.; Kiyono, H.; Iwamoto, R.; Isobe, Y.; Arita, M.; et al. Polyunsaturated Fatty Acid Saturation by Gut Lactic Acid Bacteria Affecting Host Lipid Composition. Proc. Natl. Acad. Sci. USA 2013, 110, 17808-17813. [CrossRef]

53. Yang, B.; Chen, H.; Song, Y.; Chen, Y.Q.; Zhang, H.; Chen, W. Myosin-Cross-Reactive Antigens from Four Different Lactic Acid Bacteria Are Fatty Acid Hydratases. Biotechnol. Lett. 2013, 35, 75-81. [CrossRef]

54. Volkov, A.; Khoshnevis, S.; Neumann, P.; Herrfurth, C.; Wohlwend, D.; Ficner, R.; Feussner, I. Crystal Structure Analysis of a Fatty Acid Double-Bond Hydratase from Lactobacillus Acidophilus. Acta Cryst. Sect. D Biol. Cryst. 2013, 69, 648-657. [CrossRef]

55. Jo, Y.S.; An, J.U.; Oh, D.K. $\gamma$-Dodecelactone Production from Safflower Oil via 10-Hydroxy-12 (z)-Octadecenoic Acid Intermediate by Whole Cells of Candida Boidinii and Stenotrophomonas Nitritireducens. J. Agric. Food Chem. 2014, 62, 6736-6745. [CrossRef] [PubMed]

56. Park, J.Y.; Lee, S.H.; Kim, K.R.; Park, J.B.; Oh, D.K. Production of 13S-Hydroxy-9 (Z)-Octadecenoic Acid from Linoleic Acid by Whole Recombinant Cells Expressing Linoleate 13-Hydratase from Lactobacillus acidophilus. J. Biotechnol. 2015, 208, 1-10. [CrossRef]

57. Hirata, A.; Kishino, S.; Park, S.-B.; Takeuchi, M.; Kitamura, N.; Ogawa, J. A Novel Unsaturated Fatty Acid Hydratase toward C16 to C22 Fatty Acids from Lactobacillus acidophilus. J. Lipid Res. 2015, 56, 1340-1350. [CrossRef]

58. Takeuchi, M.; Kishino, S.; Park, S.B.; Hirata, A.; Kitamura, N.; Saika, A.; Ogawa, J. Efficient Enzymatic Production of Hydroxy Fatty Acids by Linoleic Acid $\Delta 9$ Hydratase from Lactobacillus Plantarum AKU 1009a. J. Appl. Microbiol. 2016, 120, 1282-1288. [CrossRef]

59. Schmid, J.; Steiner, L.; Fademrecht, S.; Pleiss, J.; Otte, K.B.; Hauer, B. Biocatalytic Study of Novel Oleate Hydratases. J. Mol. Catal. B Enzym. 2016, 133, 243-249. [CrossRef]

60. Choi, J.H.; Seo, M.J.; Lee, K.T.; Oh, D.K. Biotransformation of Fatty Acid-Rich Tree Oil Hydrolysates to Hydroxy Fatty Acid-Rich Hydrolysates by Hydroxylases and Their Feasibility as Biosurfactants. Biotechnol. Bioprocess Eng. 2017, 22, 709-716. [CrossRef]

61. Meier, M.A.R.; Metzger, J.O.; Schubert, U.S. Plant Oil Renewable Resources as Green Alternatives in Polymer Science. Chem. Soc. Rev. 2007, 36, 1788-1802. [CrossRef]

62. Heo, S.H.; Hou, C.T.; Kim, B.S. Production of Oxygenated Fatty Acids from Vegetable Oils by Flavobacterium sp. Strain DS5. New Biotechnol. 2009, 26, 105-108. [CrossRef]

63. Kang, W.R.; Seo, M.J.; Shin, K.C.; Park, J.B.; Oh, D.K. Gene Cloning of an Efficiency Oleate Hydratase from Stenotrophomonas Nitritireducens for Polyunsaturated Fatty Acids and Its Application in the Conversion of Plant Oils to 10-Hydroxy Fatty Acids. Biotechnol. Bioeng. 2017, 114, 74-82. [CrossRef]

64. Jeon, E.Y.; Seo, J.H.; Kang, W.R.; Kim, M.J.; Lee, J.H.; Oh, D.K.; Park, J.B. Simultaneous Enzyme/Whole-Cell Biotransformation of Plant Oils into C9 Carboxylic Acids. ACS Catal. 2016, 6, 7547-7553. [CrossRef]

65. Kim, S.K.; Park, Y.C. Biosynthesis of $\omega$-Hydroxy Fatty Acids and Related Chemicals from Natural Fatty Acids by Recombinant Escherichia Coli. Appl. Microbiol. Biotechnol. 2019, 103, 191-199. [CrossRef]

66. Song, J.W.; Lee, J.H.; Bornscheuer, U.T.; Park, J.B. Microbial Synthesis of Medium-Chain $\alpha$, $\omega$-Dicarboxylic Acids and $\omega$-Aminocarboxylic Acids from Renewable Long-Chain Fatty Acids. Adv. Synth. Catal. 2014, 356, 1782-1788. [CrossRef] 
67. Oh, H.J.; Kim, S.U.; Song, J.W.; Lee, J.H.; Kang, W.R.; Jo, Y.S.; Kim, K.R.; Bornscheuer, U.T.; Oh, D.K.; Park, J.B. Biotransformation of Linoleic Acid into Hydroxy Fatty Acids and Carboxylic Acids Using a Linoleate Double Bond Hydratase as Key Enzyme. Adv. Synth. Catal. 2015, 357, 408-416. [CrossRef]

68. Lee, D.S.; Song, J.W.; Voß, M.; Schuiten, E.; Akula, R.K.; Kwon, Y.U.; Bornscheuer, U.; Park, J.B. Enzyme Cascade Reactions for the Biosynthesis of Long Chain Aliphatic Amines from Renewable Fatty Acids. Adv. Synth. Catal. 2019, 361, 1359-1367. [CrossRef]

69. Wu, Y.X.; Pan, J.; Yu, H.L.; Xu, J.H. Enzymatic Synthesis of 10-Oxostearic Acid in High Space-Time Yield via Cascade Reaction of a New Oleate Hydratase and an Alcohol Dehydrogenase. J. Biotechnol. X 2019. [CrossRef]

70. Song, J.W.; Jeon, E.Y.; Song, D.H.; Jang, H.Y.; Bornscheuer, U.T.; Oh, D.K.; Park, J.B. Multistep Enzymatic Synthesis of Long-Chain $\alpha, \omega$-Dicarboxylic and $\omega$-Hydroxycarboxylic Acids from Renewable Fatty Acids and Plant Oils. Angew. Chem. Int. Ed. 2013, 52, 2534-2537. [CrossRef]

71. Kim, S.U.; Kim, K.R.; Kim, J.W.; Kim, S.; Kwon, Y.U.; Oh, D.K.; Park, J.B. Microbial Synthesis of Plant Oxylipins from $\gamma$-Linolenic Acid through Designed Biotransformation Pathways. J. Agric. Food Chem. 2015, 63, 2773-2781. [CrossRef]

72. Koppireddi, S.; Seo, J.H.; Jeon, E.Y.; Chowdhury, P.S.; Jang, H.Y.; Park, J.B.; Kwon, Y.U. Combined Biocatalytic and Chemical Transformations of Oleic Acid to $\omega$-Hydroxynonanoic Acid and $\alpha, \omega$-Nonanedioic Acid. Adv. Synth. Catal. 2016, 358, 3084-3092. [CrossRef]

73. Cha, H.J.; Seo, E.J.; Song, J.W.; Jo, H.J.; Kumar, A.R.; Park, J.B. Simultaneous Enzyme/Whole-Cell Biotransformation of C18 Ricinoleic Acid into (R)-3-Hydroxynonanoic Acid, 9-Hydroxynonanoic Acid, and 1, 9-Nonanedioic Acid. Adv. Synth. Catal. 2018, 360, 696-703. [CrossRef]

74. Farbood, M.I.; Morris, J.A.; McLean, L.B. Fermentation Process for Preparing 10-Hydroxy-C18-Carboxylic Acid and Gamma-Dodecalactone Derivatives. EP078388A25, 1 December 1994.

75. Park, A.K.; Lee, G.H.; Kim, D.W.; Jang, E.H.; Kwon, H.T.; Chi, Y.M. Crystal structure of oleate hydratase from Stenotrophomonas sp. KCTC 12332 reveals conformational plasticity surrounding the FAD binding site. Biochem. Biophys. Res. Commun. 2018, 499, 772-776. [CrossRef]

76. Lorenzen, J.; Driller, R.; Waldow, A.; Qoura, F.; Loll, B.; Brück, T. Rhodococcus erythropolis Oleate Hydratase: A New Member in the Oleate Hydratase Family Tree-Biochemical and Structural Studies. ChemCatChem 2018, 10, 407-414. [CrossRef]

77. Demming, R.M.; Hammer, S.C.; Nestl, B.M.; Gergel, S.; Fademrecht, S.; Pleiss, J.; Hauer, B. Asymmetric Enzymatic Hydration of Unactivated, Aliphatic Alkenes. Angew. Chem. Int. Ed. 2019, 58, 173-177. [CrossRef]

78. Eser, B.E.; Poborsky, M.; Dai, R.; Kishino, S.; Ljubic, A.; Takeuchi, M.; Jacobsen, C.; Ogawa, J.; Kristensen, P.; Guo, Z. Rational Engineering of Hydratase from Lactobacillus Acidophilus Reveals Critical Residues Directing Substrate Specificity and Regioselectivity. ChemBioChem 2019. [CrossRef]

79. Engleder, M.; Strohmeier, G.A.; Weber, H.; Steinkellner, G.; Leitner, E.; Müller, M.; Mink, D.; Schürmann, M.; Gruber, K.; Pichler, H. Evolving the Promiscuity of Elizabethkingia Meningoseptica Oleate Hydratase for the Regio- and Stereoselective Hydration of Oleic Acid Derivatives. Angew. Chem. Int. Ed. 2019, 58, 7480-7484. [CrossRef]

(C) 2020 by the authors. Licensee MDPI, Basel, Switzerland. This article is an open access article distributed under the terms and conditions of the Creative Commons Attribution (CC BY) license (http://creativecommons.org/licenses/by/4.0/). 